ЕЖОВ Дмитрий Александрович - кандидат политических наук, доцент; доцент департамента политологии факультета социальных наук и массовых коммуникаций Финансового университета при Правительстве РФ (125993, Россия, г. Москва, ГСП-3, Ленинградский пр-кт, 49; president@ lenta.ru)

\title{
О НАЦИОНАЛЬНЫХ ЦЕЛЯХХ РАЗВИТИЯ РОССИЙСКОЙ ФЕДЕРАЦИИ ДО 2030 ГОДА В КОНТЕКСТЕ ПОСТРОЕНИЯ ЭФФЕКТИВНОГО ГОСУДАРСТВА
}

\begin{abstract}
Аннотация. В статье анализируются национальные цели развития Российской Федерации до 2030 г. в контексте построения эффективного государства. Отдельное внимание уделяется сравнению целевых показателей, характеризующих достижение национальных целей к 2030 г., с аналогичными показателями, фигурировавшими в указе Президента РФ от 7 мая 2018 г. Автор подчеркивает, что отдельные временные ориентиры достижения целевых показателей скорректированы с учетом объективных обстоятельств.
\end{abstract}

Ключевые слова: национальные цели, национальные проекты, целевые показатели, эффективное государство, стратегия развития государства.

21 июля 2020 г. президент РФ В.В. Путин подписал указ «О национальных целях развития Российской Федерации на период до 2030 года». В условиях преодоления последствий пандемии коронавирусной инфекции, адаптации к новой реальности и обеспечения стабильного функционирования социальных и государственных институтов в обозримой перспективе анализ содержания документа в контексте построения эффективного государства представляется более чем актуальным.

Новый, «июльский» указ уточняет стратегические приоритеты, обозначенные двумя годами ранее в указе Президента РФ от 7 мая 2018 г. «О национальных целях и стратегических задачах развития Российской Федерации на период до 2024 года», устанавливающем и утверждающем национальные проекты России. С учетом объективно развивающейся ситуации и совокупности внешних факторов в «июльском» указе утверждаются пять национальных целей: 1) сохранение населения, здоровье и благополучие людей; 2) возможности самореализации и развития талантов; 3 ) комфортная и безопасная среда для жизни; 4) достойный, эффективный труд и успешное предпринимательство; 5) цифровая трансформация. Стоит отметить, что в указе 2018 года были сформулированы девять национальных целей. Представляется очевидным, что новые национальные цели содержательно укрупнены. Далее остановимся на анализе целевых показателей, характеризующих достижение национальных целей к 2030 г., в контексте их сравнения с аналогичными показателями, фигурировавшими в указе Президента РФ от 7 мая 2018 г.

Принципиальными в рамках национальной цели «Сохранение населения, здоровье и благополучие людей» являются три показателя. В первую очередь, это установление ожидаемой продолжительности жизни к 2030 г. на уровне 78 лет. В сравнении с аналогичным показателем в указе от 7 мая 2018 г. увеличен период целедостижения, ранее установленный на отметке 2024 г. Во-вторых, уровень бедности к 2030 г. должен снизиться в два раза по сравнению с показателем 2017 г. В-третьих, долю россиян, систематически занимающихся физ- 
культурой и спортом, поручено увеличить до 70\%, в то время как изначально ставилась цель довести ее до 55\% к 2024 г.

В рамках национальной цели «Возможности для самореализации и развития талантов» к 2030 г. Российская Федерация должна войти в первую десятку стран по качеству общего образования. Здесь стоит заметить, что аналогичная задача к 2024 г. ставилась в рамках национального проекта «Образование». Также, согласно тексту «июльского» указа, Россия должна войти в первую десятку стран по объему научных исследований и разработок, в т.ч. за счет создания эффективной системы высшего образования. Ранее предполагалось, что Российская Федерация станет одной из пяти ведущих стран по исследованиям в областях, определенных в качестве приоритетов научнотехнологического развития. Доля волонтеров и добровольцев среди россиян к 2030 г. должна возрасти до 15\%. Ранее вовлечь в добровольческое движение предполагалось не менее $20 \%$ жителей страны. В качестве показателей в рамках национальной цели «Возможности для самореализации и развития талантов» обозначаются создание условий для воспитания гармонично развитой и социально ответственной личности на основе духовно-нравственных ценностей народов Российской Федерации, исторических и национальнокультурных традиций и увеличение числа посещений культурных мероприятий в три раза по сравнению с показателем 2019 г. Достижение этих показателей с высокой долей очевидности будет способствовать увеличению удельного веса мировоззренческо-ценностной составляющей в сознании граждан Российской Федерации.

Национальная цель «Комфортная и безопасная среда для жизни» предполагает улучшение жилищных условий не менее 5 млн семей ежегодно и увеличение объема жилищного строительства не менее чем до 120 млн кв. м в год. Эта же задача ставилась и к 2024 г., однако, по мнению куратора национального проекта «Жилье и городская среда» М.Ш. Хуснуллина, соответствующего показателя удастся достичь к 2026-2027 гг. при условии сохранения программы льготной ипотеки. Целевой показатель, выраженный в обеспечении доли дорожной сети в крупнейших городских агломерациях, соответствующей нормативным требованиям, на уровне не менее $85 \%$, созвучен цели национального проекта «Безопасные и качественные автомобильные дороги». Важными в контексте создания более благоприятной экологической среды являются такие показатели, как снижение выбросов опасных загрязняющих веществ, оказывающих наибольшее негативное воздействие на окружающую среду и здоровье человека, в два раза, а также ликвидация наиболее опасных объектов накопленного вреда окружающей среде и экологическое оздоровление водных объектов, включая реку Волгу, озера Байкал и Телецкое.

В рамках национальной цели «Достойный, эффективный труд и успешное предпринимательство» принципиальным является смещение ориентиров достижения реального роста экспорта несырьевых неэнергетических товаров не менее $70 \%$ по сравнению с показателем 2020 г. (в 2024 г. его объем должен был достичь 250 млрд долл. ежегодно). Цель довести число занятых в сфере малого и среднего бизнеса, включая индивидуальных предпринимателей и самозанятых, до 25 млн чел. в соответствии с вновь установленными показателями отложена с 2024 до 2030 г. Важно также отметить установление в качестве целевого показателя обеспечение темпа устойчивого роста доходов населения и уровня пенсионного обеспечения не ниже инфляции как соответствующего духу текста Конституции РФ с поправками по состоянию на 2020 г., принятыми в результате общероссийского голосования 1 июля 2020 г.

В рамках национальной цели «Цифровая трансформация» должно осущест- 
вляться достижение «цифровой зрелости» ключевых отраслей экономики и социальной сферы, в т.ч. здравоохранения и образования, а также государственного управления; увеличение доли массовых социально значимых услуг, доступных в электронном виде, до 95\%; увеличение вложений в отечественные решения в сфере информационных технологий в четыре раза по сравнению с показателем 2019 г. В качестве целевого показателя устанавливается обеспечение возможности широкополосного доступа к сети Интернет для 97\% домохозяйств. Ранее аналогичная цель ставилась к 2024 г.

Таким образом, мы видим, что национальные цели развития Российской Федерации до 2030 года в целом сопоставимы с аналогичными целями, установленными указом Президента РФ от 7 мая 2018 г., и способствуют построению эффективного государства. В то же время отдельные временные ориентиры достижения целевых показателей скорректированы с учетом объективных обстоятельств.

Статья подготовлена по результатам исследований, выполненныхза счет бюджетныхсредств по государственному заданию Финуниверситету (2020).

EZHOV Dmitriy Aleksandrovich, Cand.Sci. (Pol.Sci.), Associate Professor; Associate Professor of the Department of Political Science, Faculty of Social Sciences and Mass Communications, Financial University under the Government of the Russian Federation (49 Leningradsky Ave, GSP-3, Moscow, Russia, 125993; president@lenta.ru)

\section{ABOUT THE NATIONAL DEVELOPMENT GOALS OF THE RUSSIAN FEDERATION UNTIL 2030 IN THE CONTEXT OF BUILDING AN EFFECTIVE STATE}

Abstract. The article analyzes the national development goals of the Russian Federation until 2030 in the context of building an effective state. Special attention is paid to the comparison of target indicators characterizing the achievement of national goals by 2030 with similar indicators that appeared in the Decree of the President of the Russian Federation of May 7, 2018. The author emphasizes that some time guidelines for achieving target indicators have been adjusted taking into account objective circumstances.

Keywords: national goals, national projects, target indicators, effective state, state development strategy 